\title{
IgE-induced passive sensitization of human isolated bronchi and lung mast cells
}

\author{
J.M. Tunon de Lara*+, Y. Okayama\#, J-P. Savineau*, R. Marthan*
}

IgE-induced passive sensitization of human isolated bronchi and lung mast cells. J.M. Tunon de Lara, Y. Okayama, J-P. Savineau, R. Marthan. (C)ERS Journals Ltd 1995.

ABSTRACT: Passive sensitization of human isolated lung with serum from atopic asthmatic patients provides an opportunity to study the link between airway hyperresponsiveness and the allergic process. To directly demonstrate the role of immunoglobulin $E$ (IgE) in the effect of the atopic serum, we have compared the effect of passively sensitizing both human bronchi and isolated lung mast cells with either serum from atopic asthmatic patients or human monoclonal IgE.

Peripheral bronchi ( $<5 \mathrm{~mm}$ in internal diameter) were dissected out from human lung obtained at thoractomy and isometric contraction was studied in response to a variety of immunological stimuli according to the sensitization protocol. Mast cells were also isolated from human lung and histamine release was measured under similar experimental conditions.

A contractile response was elicited by either the specific antigen or anti-IgE $\left(0.6-600 \mathrm{ng} \cdot \mathrm{mL}^{-1}\right)$ but not anti-immunoglobulin $\left.\mathrm{G}(\mathrm{IgG}) 0.2-20 \mu \mathrm{g} \cdot \mathrm{mL}^{-1}\right)$ in airways sensitized with atopic serum (total IgE concentration of approximately 1,000 international units $\left.(\mathrm{IU}) \cdot \mathrm{mL}^{-1}\right)$. The maximal contractile response to anti-IgE was $75 \pm 22 \%$ of the response to $1 \mathrm{mM}$ acetylcholine. Similarly, anti-IgE released histamine from isolated lung mast cells sensitized with atopic serum up to $22.4 \pm 2 \%$ of total histamine measured within mast cells. When isolated airways or mast cells were sensitized with human monoclonal IgE $\left(1,000 \mathrm{IU} \cdot \mathrm{mL}^{-1}\right)$, response to anti-IgE in terms of contractile response or histamine release, respectively, were not significantly different from those obtained following passive sensitization with atopic serum. Finally, the bronchial contractile response to anti-IgE depended not only on the concentration of anti-IgE but also on that of $\operatorname{IgE}\left(300-2,000 \mathrm{IU} \cdot \mathrm{mL}^{-1}\right)$ used to sensitize the airways.

These results indicate that the effect of antigen or anti-IgE in peripheral bronchi passively sensitized with atopic serum is mimicked when sensitization is carried out directly with human monoclonal IgE.

Eur Respir J., 1995, 8, 1861-1865.

Passive sensitization of human isolated airways with serum from allergic patients provides an opportunity to study the interaction between allergic factors and smooth muscle behaviour, the pathway between allergy and airway dysfunction being likely to involve immunoglobulins, in particular immunoglobulin $\mathrm{E}$ (IgE) [1].

Passively sensitized airways can be used to study immediate hypersensitivity, i.e. the response to antigen [2, 3], or airway smooth muscle responsiveness prior to the specific antigen challenge [4]. In the former type of study, it has recently been demonstrated that the antigen-induced contractile response is related to mast cell mediator release and can be mimicked, to some extent, by anti-IgE stimulation, although there are qualitative differences between central and peripheral bronchi [5]. In the latter type of study, it has been observed that passive sensitization alters human airway responsiveness independently of any antigen challenge not only in terms of force generation, as shown by us [4, 6-8] and RABE et al. [9], but also in terms of shortening velocity

\section{Tissue preparation}

*Laboratoire de Physiologie, Université de Bordeaux II, Bordeaux France, ${ }^{+}$Service des Maladies Respiratoires, Centre Hospitalier Universitaire de Bordeaux, France and \#Immunopharmacology Group, Southampton, UK.

Correspondence: R. Marthan

Laboratoire de Physiologie

Université de Bordeaux II

146 rue Léo Saignat

33076 Bordeaux Cédex

France

Keywords: Airways smooth muscle anti-immunoglobulin E asthma

human isolated bronchus immunoglobulin E mast cells

Received: April 241995

Accepted after revision August 161995

This work was supported by grants from Institut National de la Santé et de la Recherche Médicale (INSERM, CRE 910411), Association Recherche et Partage, Pôle Médicament d'Aquitaine, and by a contribution from the Institut Pneumologique d'Aquitaine.

and capacity [10]. The link between the atopic serum and the alteration in airway responsiveness is not as yet defined but may be IgE since, in all of the abovementioned studies, human atopic serum was selected on the basis of an elevated concentration of total $\mathrm{IgE}$.

To directly demonstrate that $\mathrm{IgE}$ concentration in atopic serum is responsible for the effect of the specific antigen or even anti-IgE, the effects of the atopic serum should be mimicked by IgE. In the present report, we have compared the immediate hypersensitivity response both in human bronchi and isolated lung mast cells sensitized with atopic serum or human monoclonal IgE.

\section{Methods}

Human lung was obtained from 20 patients at thoracotomy, as described previously $[6,8]$. These patients 
(14 males and 6 females, aged 42-68 yrs) were current or ex-smokers and underwent resection for pulmonary carcinoma. As in previous studies, specimens were selected from patients whose lung function was within the normal range, i.e. forced expiratory volume in one second (FEV1) measured before surgery in our Lung Function Testing Laboratory in the Hospital was above $80 \%$ of predicted. Moreover, analysis of the medical record of the patients revealed that none of them had a history of atopy. Finally, for all patients whose lung was studied, total serum IgE concentration was measured and found to be below 100 international units (IU) $\mathrm{mL}^{-1}$. After resection, the specimens were immediately transferred to the laboratory in an ice-cold oxygenated KrebsHenseleit solution (KHS) (composition in $\mathrm{mM}: \mathrm{NaCl}$ $118.4, \mathrm{KCl} 4.7, \mathrm{CaCl}_{2} .2 \mathrm{H}_{2} \mathrm{O} 2.5, \mathrm{MgSO}_{4} .7 \mathrm{H}_{2} \mathrm{O} 1.2$, $\mathrm{KH}_{2} \mathrm{PO}_{4}$ 1.2, $\mathrm{NaHCO}_{3} 25.0$, D-glucose 11.1). From a macroscopically tumour-free part of each specimen, segments of bronchi $30-40 \mathrm{~mm}$ in length and $3-4 \mathrm{~mm}$ in internal diameter were carefully dissected from surrounding parenchyma without damaging the airway mucosal membrane. Segments of bronchi were then cut into rings measuring $4-5 \mathrm{~mm}$ in length.

\section{Passive sensitization}

Human isolated airways were sensitized, either as described previously [4, 6-8] with nondiluted serum pool from atopic asthmatic subjects whose concentration both of total and specific IgE to Dermatophagoides pteronyssinus (D. pter.) was above $1,000 \mathrm{IU} \cdot \mathrm{mL}^{-1}$ and $17.5 \mathrm{Phad}-$ ebas radioallergosorbent test (RAST) units (PRU) $\cdot \mathrm{mL}^{-1}$ (i.e. 4+ RAST titre), respectively, or with KHS supplemented with human immunoglobulins (IgE or IgG, according to the sensitization protocol). Sensitization was carried out once it had been checked that each of the lung specimens was not spontaneously sensitized to one of the two different most common allergens in the area, i.e. house dust mite and grass pollen. This was tested by the fact that administration of $0.05 \mathrm{~mL}$, i.e. 300 units (U), of these two allergens to a single bronchial ring did not elicit a contractile response (see Mechanical recordings). The remaining rings were then divided into two paired groups. One group was passively sensitized by incubation overnight at room temperature in either the above described atopic serum or KHS supplemented with a defined concentration of immunoglobulins. The other group acted as control and remained nonsensitized by similar incubation overnight in a nondiluted serum pool from nonasthmatic nonatopic subjects, whose total $\mathrm{IgE}$ concentration was below $10 \mathrm{IU} \cdot \mathrm{mL}^{-1}$. Solutions or serum used for overnight incubation were supplemented with penicillin and tobramycin $\left(3 \times 10^{-5}\right.$ and $5 \times 10^{-3} \mathrm{~g} \cdot \mathrm{L}^{-1}$, respectively), to avoid bacterial growth.

\section{Mechanical recordings}

The next morning, the paired human isolated bronchial rings were mounted in $20 \mathrm{~mL}$ vertical organ baths of an automatic system (isolated organ system $\left(\mathrm{IOS}_{1}\right)$;
EMKA Technologies, Paris, France) filled with KHS, $\mathrm{pH} 7.4$, bubbled with $5 \% \mathrm{CO}_{2}$ in $\mathrm{O}_{2}$, and maintained at $37^{\circ} \mathrm{C}$. Each ring was connected to an isometric force transducer (EMKA Technologies). The resting tension was adjusted to a $1.5 \mathrm{~g}$ load on the basis of a separate series of experiments in which length-tension curves constructed for this type of preparation indicated that this load was optimal [8]. As suggested by Mitchell et al. [11], this load can be used in subsequent experiments conducted in the same type of tissue. Each ring was first stimulated with a supramaximal concentration of acetylcholine (ACh) (final bath concentration $10^{-3} \mathrm{M}$ ) and the contractile response used as the reference response. After removal of ACh by repeated washing of the tissue, when stable resting tone had returned to baseline, either antigen $(D$. pter. $0.05 \mathrm{~mL}(300 \mathrm{U}))$ or anti-IgE (0.6-600 ng. $\left.\mathrm{mL}^{-1}\right)$ was administered and the amplitude of the response of each ring was expressed, normalized to the maximal ACh contraction in that ring.

\section{Isolation of human lung mast cells}

Normal lung tissue including peripheral airways (3$5 \mathrm{~mm}$ internal diameter) obtained from nonatopic patients was chopped with scissors into fragments of 0.5-2 $\mathrm{mm}^{3}$ and dispersed by an enzymatic procedure using collagenase and hyaluronidase $\left(1 \mathrm{~g}\right.$ tissue $4 \mathrm{~mL}^{-1}$ minimum essential medium (MEM) supplemented with $2 \%$ foetal calf serum and containing $1.5 \mathrm{mg} \cdot \mathrm{mL}^{-1}$ type IA collagenase and $0.75 \mathrm{mg} \cdot \mathrm{mL}^{-1}$ type I hyaluronidase) as described previously [12]. Dispersed cells were separated from undissociated tissue by filtration and washed three times with MEM by centrifugation $\left(500 \times \mathrm{g}\right.$ for $8 \mathrm{~min}$ at $\left.20^{\circ} \mathrm{C}\right)$. After removal of erythrocytes by centrifugation through a $65 \%$ continuous Percoll gradient, T-lymphocytes were removed from dispersed mast cells using a monoclonal antibody directed against CD2 coupled to magnetic beads (Dynabeads M450 Pan-T, Dynal, UK). Mast cells were then purified using an immunomagnetic procedure with the anti-c-kit monoclonal antibody YB5.B8 as described previously [13]. Briefly, cells were incubated for $30 \mathrm{~min}$ at room temperature with a solution of monoclonal antibody YB5.B8 $\left(5 \mu \mathrm{g} \cdot \mathrm{mL}^{-1}\right)$, washed and incubated for $60 \mathrm{~min}$ with a suspension of magnetic beads coated with a goat anti-mouse $\operatorname{IgG}$ antibody at $4^{\circ} \mathrm{C}$ on a roller. Purified mast cells attached to magnetic beads were thereafter collected with a magnet and magnetic beads were removed by centrifugation. A final solution of purified lung mast cells was obtained with a purity ranging $85-95 \%$. Mast cell number and viability were assessed by counting in a NeuBauer haemocytometer after Kimura staining [13].

\section{Measurement of histamine release}

In isolated lung mast cells, sensitization was carried out as described above for airway rings, i.e. either with atopic serum or with buffer supplemented with immunoglobulin. Sensitized mast cells were washed and challenged 
with anti- $\operatorname{IgE}$ at different dilutions corresponding to concentrations ranging $0.2-6 \mu \mathrm{g} \cdot \mathrm{mL}^{-1}$. Each concentration of anti-IgE was administered in a noncumulative manner to one set of cells from one patient. Histamine was measured in supernatants as described previously [14]. After centrifugation, supernatants were diluted 1:20 in culture medium to achieve a final concentration of $5 \times 10^{3} .50$ $\mu \mathrm{L}^{-1}$. The diluted supernatants were incubated in triplicate in glass fibre-prepared microtitre plates for $60 \mathrm{~min}$ at $37^{\circ} \mathrm{C}$. Histamine bound to the glass fibre matrix was released by adding a mixture of o-phthaldialdehyde reagent to each well. The reaction was stopped by adding $0.6 \% \mathrm{HClO}_{4}$ and histamine fluorescence values were measured using a Gilson 121 fluorometer and autosampler. For mast cells isolated from each patient, histamine release values were expressed as percentage of total histamine measured within mast cells after disruption by $5 \%$ trichloroacetic acid and results are given as mean values obtained from different patients.

\section{Drugs}

The following drugs were used: acetylcholine, human polyclonal IgG, anti-human IgG, collagenase type IA and hyaluronidase type I from Sigma (Saint-Quentin-Fallavier, France); house dust mite (Dermatophagoides ptenonyssinus), grass pollen (Phleum pratense) 1:100 w/v, 10,000 protein nitrogen units. $\mathrm{mL}^{-1}$ from Institut Pasteur (Paris, France); human monoclonal IgE from Calbiochem (La Jolla, USA); goat anti-human IgE from Immunotech (Marseille, France); the anti-c-kit monoclonal antibody YB5.B8 was a gift from Dr L.K. Ashman, Melbourne, Australia.

\section{Results}

Figure 1 illustrates the effect of a variety of immunological stimulations of human isolated airways rings incubated overnight in normal or atopic serum or in KHS supplemented with immunoglobulins. As expected, nonsensitized tissues did not respond to antigen (D. pter), whereas paired tissues passively sensitized with atopic serum contracted in response to stimulation with $D$. pter (fig. 1a). Paired tissues sensitized with atopic serum contracted concentration-dependently to anti-IgE (0.6$\left.600 \mathrm{ng} \cdot \mathrm{mL}^{-1}\right)$ but not to anti-IgG $\left(0.2-20 \mu \mathrm{g} \cdot \mathrm{mL}^{-1}\right.$ ) (fig. 1b). Finally, when paired tissues were incubated overnight in serum supplemented with immunoglobulins, IgE $\left(1,000 \mathrm{IU} \cdot \mathrm{mL}^{-1}\right)$ or $\mathrm{IgG}\left(0.25 \mathrm{mg} \cdot \mathrm{mL}^{-1}\right)$, and then challenged with the corresponding anti-immunoglobulin, unlike anti-IgG, anti-IgE contracted airways rings in a concentration-dependent manner (fig. 1c).

The amplitude of the response to anti-IgE was concentration-dependent (fig. 2a) and consistent whether passive sensitization was carried out with atopic serum or KHS supplemented with a concentration of human monoclonal IgE similar to that in the atopic serum, i.e. 1,000 $\mathrm{IU} \cdot \mathrm{mL}^{-1}$. In addition, the amplitude of the maximal response to anti-IgE $\left(600 \mathrm{ng} \cdot \mathrm{mL}^{-1}\right)$ was also dependent a)

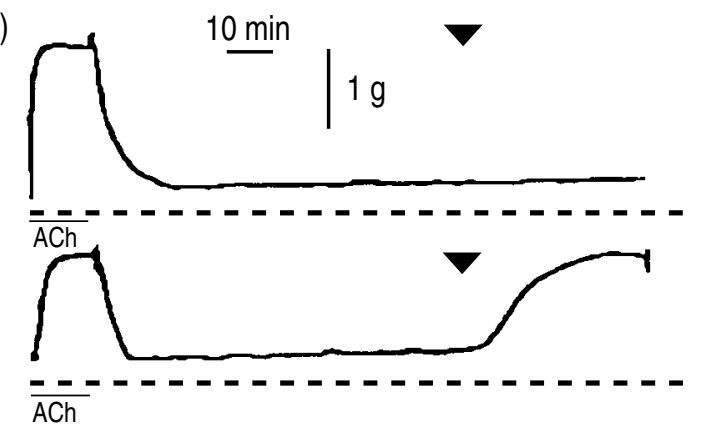

b)

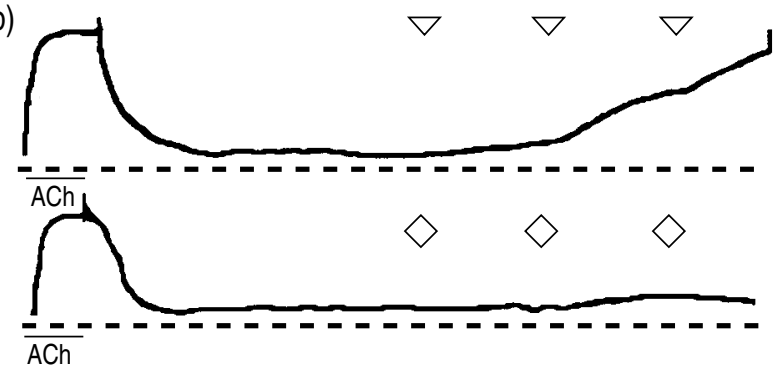

c)

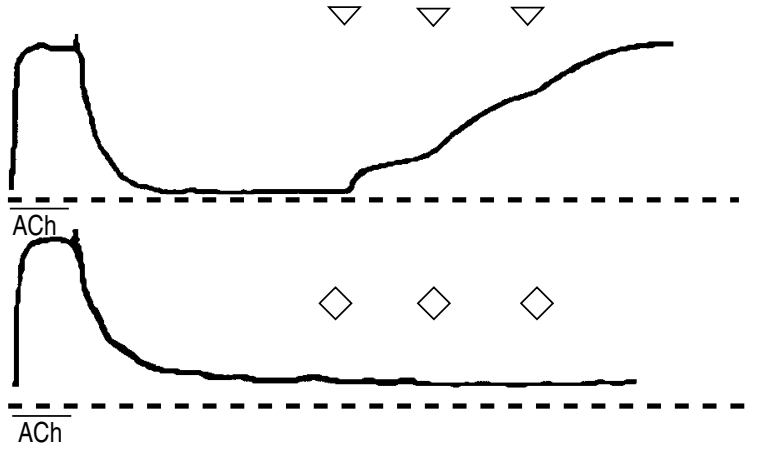

Fig. 1. - Examples of contractile responses to immunological stimuli in human isolated bronchi following a maximal contraction to acetylcholine (ACh, $1 \mathrm{mM})$. a) Response to $D$. $\operatorname{pter}(\boldsymbol{\nabla})$ of a pair of airway rings (from the same patient) incubated in normal serum (upper trace) or atopic serum (lower trace). b) Response to anti-immunoglobulins of a pair of airway rings incubated in atopic serum challenged with anti-immunoglobulin E (IgE) $(\nabla)\left(0.6-600 \mathrm{ng} \cdot \mathrm{mL}^{-1}\right)$ (upper trace) or anti-immunoglobulin $\mathrm{G}(\mathrm{IgG})(\diamond)\left(0.2-20 \mu \mathrm{g} \cdot \mathrm{mL}^{-1}\right)$ (lower trace). c) Response to anti-immunoglobulins of a pair of airways incubated in buffer supplemented with human immunoglobulins: response to anti$\operatorname{IgE}(\nabla)\left(0.6-600 \mathrm{ng} \cdot \mathrm{mL}^{-1}\right)$ following incubation with $1,000 \mathrm{IU} \cdot \mathrm{mL}^{-1} \mathrm{IgE}$ (upper trace) and response to anti-IgG $(\diamond)\left(0.2-20 \mu \mathrm{g} \cdot \mathrm{mL}^{-1}\right)$ (lower trace) following incubation with $0.25 \mathrm{mg} \cdot \mathrm{mL}^{-1} \mathrm{IgG}$. IU: international units.

on the concentration of monoclonal $\operatorname{IgE}$ added to the KHS used to passively sensitize the tissues (fig. $2 b$ ). Contractile responses to anti-IgE were elicited for $\mathrm{IgE}$ concentrations higher than $300 \mathrm{IU} \cdot \mathrm{mL}^{-1}$. When IgE concentration was twice that of the atopic serum, i.e. 2, IU. $\mathrm{mL}^{-1}$, the amplitude of the response was further increased.

Histamine release from isolated lung mast cells was also dependent on anti-IgE concentration. As shown in table 1, the higher the concentration of anti-IgE (0.2-6 $\left.\mu \mathrm{g} \cdot \mathrm{mL}^{-1}\right)$ the greater the amount of histamine released from lung mast cells, whatever the conditions of sensitization. However, we observed an increase in histamine release from lung mast cells passively sensitized with either atopic serum or human monoclonal $\operatorname{IgE}$ when 
a)

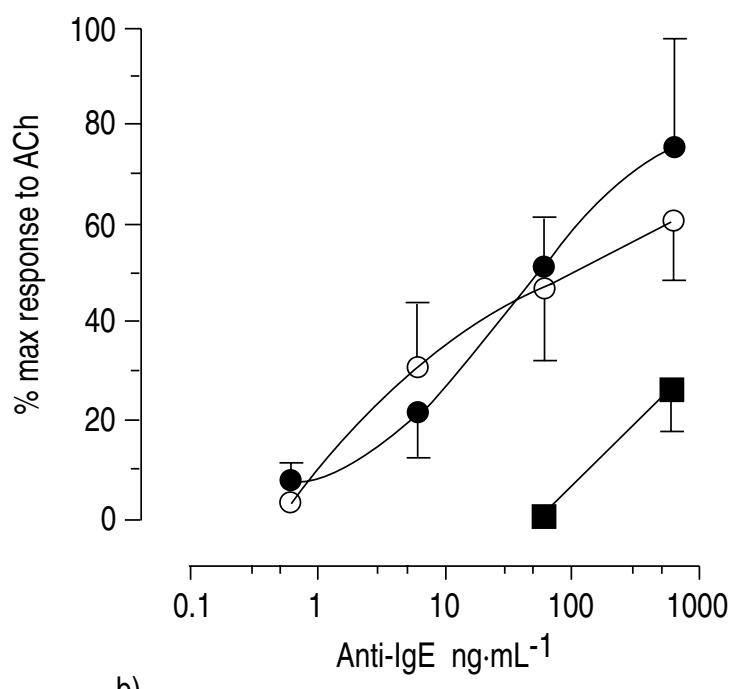

b)

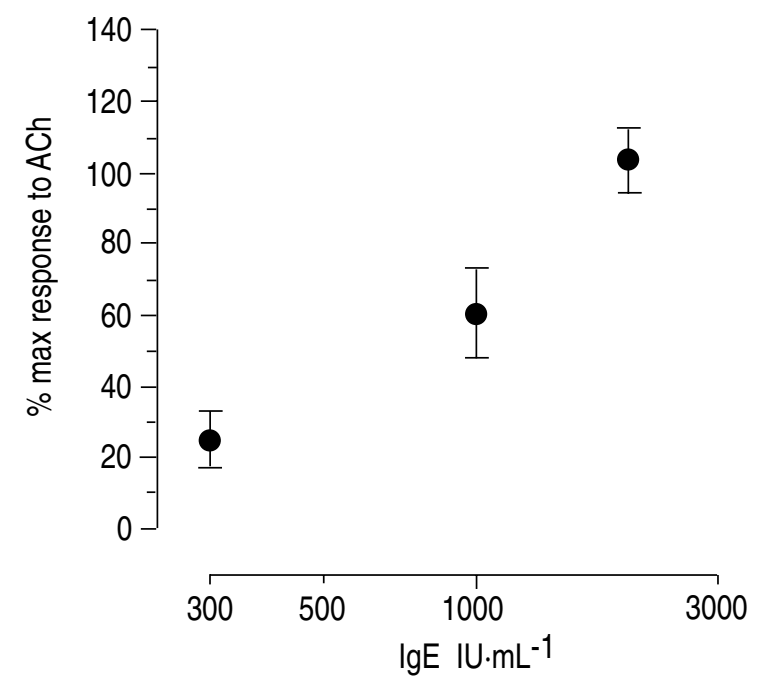

Fig. 2. - a) Contraction response curve to anti-IgE in human isolated airway rings nonsensitized ( atopic serum (- - ) or with buffer supplemented with human monoclonal IgE 1,000 IU.mL-1 (—_ $)$. Results are calculated as the percentage of the maximal $(\max )$ response to acetylcholine (ACh, $1 \mathrm{mM}$ ) and given as mean. Vertical bars indicate SEM, $n=8$. b) Response to anti-IgE $\left(600 \mathrm{ng} \cdot \mathrm{mL}^{-1}\right)$ expressed as a percentage of the maximal response to $\mathrm{ACh}$ as a function of $\mathrm{IgE}$ concentration in the incubating buffer. For abbreviations see legend to figure 1 . compared with that from nonsensitized mast cells. In addition, no significant difference was detected in terms of histamine release between both procedures of sensitization.

\section{Discussion}

The present results confirm the findings [5], demonstrating that the immediate hypersensitivity response in passively sensitized human isolated peripheral bronchi can be elicited upon stimulation by either the specific antigen or anti-human $\operatorname{IgE}$ and that this response is associated with histamine release by isolated lung mast cells. Our study also indicates that both the anti-IgEinduced contractile response and histamine release following sensitization by atopic serum can be mimicked by incubation with human monoclonal $\operatorname{IgE}$ but not by IgG. Moreover, the amplitude of the immediate hypersensitivity response depends not only on the concentration of anti-IgE but also on the concentration of $\operatorname{IgE}$ used to sensitize isolated bronchi. Finally, since anti$\mathrm{IgE}$ is sometimes used as a model of antigen-induced responses in human airways, this study suggests that anti-IgE mimicks more closely the specific antigen provided that peripheral bronchi are passively sensitized with either atopic serum or human monoclonal IgE.

Passively sensitized human isolated airways with atopic serum have been used by several investigators to study either immediate hypersensitivity [2, 3, 5] or altered responsiveness to nonspecific agonists prior to antigen challenge [4, 6-10]. In such studies, the criterion for selecting the atopic serum is a concentration of total IgE of approximately $1,000 \mathrm{IU} \cdot \mathrm{mL}^{-1}$ associated with an elevated concentration of $\mathrm{IgE}$ directed against a specific allergen. It is commonly observed, as in the present study (fig. 1a), that passively sensitized bronchi contract in response to the specific antigen whereas nonsensitized tissues do not. Since it is believed that, in humans, sensitization is due to $\operatorname{IgE}$, anti-IgE has also been used to elicit a contractile response in human isolated airways. Anti-IgE is then used as a model of antigen-induced response even in nonsensitized tissues on the basis that various cells in human lung tissue express IgE receptors, some of which are spontaneously occupied. It has recently

Table 1. - Anti-IgE-induced histamine release in human isolated lung mast cells

\begin{tabular}{lccccc}
\hline Sensitization & $\begin{array}{c}\text { Spontaneous } \\
\text { release } \\
\%\end{array}$ & \multicolumn{4}{c}{ Anti-IgE $\left(\mu \mathrm{g} \cdot \mathrm{mL}^{-1}\right)$ induced release ${ }^{\#}$} \\
protocol & 0.2 & 0.6 & 2 & 6 \\
\hline Nonsensitized & $\leq 1.5$ & $1.1 \pm 0.3$ & $2.6 \pm 0.7$ & $4.2 \pm 1.1$ & $6.4 \pm 1.1$ \\
Atopic serum $\#$ & $\leq 1.5$ & $7.3 \pm 1.6^{\dagger}$ & $14.1 \pm 2.8^{\dagger}$ & $20 \pm 3.3^{\dagger}$ & $22.4 \pm 20^{\dagger}$ \\
IgE $^{\# \#}$ & $\leq 1.5$ & $3.7 \pm 1.1$ & $8.5 \pm 2.3$ & $12 \pm 2.4^{*}$ & $13.7 \pm 2.6^{*}$ \\
\hline
\end{tabular}

Histamine release is expressed as a percentage of total histamine measured within mast cells. \#: anti-IgE-induced histamine release was, in all cases, significantly higher than spontaneous release $(\mathrm{p}<0.05$; ANOVA test). \#\#: anti-IgE-induced histamine release was not different in mast cells sensitized with atopic serum or with human monoclonal IgE. IgE: immunoglobulin E; ANOVA: analysis of variance; IU: international units. *: $\mathrm{p}<0.05$; and $\dagger: \mathrm{p}<0.01$ (ANOVA followed by Student's $\mathrm{t}$-test), between anti-IgE-induced release in nonsensitized mast cells and in mast cells sensitized with either atopic serum or monoclonal $\operatorname{IgE}\left(1,000 \mathrm{IU} \cdot \mathrm{mL}^{-1}\right)$. Data are presented as mean $\pm \mathrm{SD}$ for $\mathrm{n}=4-6$. 
been demonstrated [5] that anti-IgE-induced contractile response in nonsensitized bronchi involved mediator release since: 1) it is blocked by a combination of the histamine receptor antagonist, pyrilamine, the cyclooxygenase inhibitor, indomethacin, and the cysteinyl leukotriene receptor antagonist, SKF 104353; and 2) anti-IgE stimulation of chopped bronchi increases histamine and eicosanoid release. We also observed that anti-IgE induces a moderate contractile response of nonsensitized bronchi and a moderate histamine release from nonsensitized isolated lung mast cells. According to ElLIS et al. [5], response of nonsensitized tissues to anti-IgE may have been limited because we studied peripheral bronchi (internal diameter $<5 \mathrm{~mm}$ ) in which, although there is a higher density of mast cells than in proximal bronchi, the number of unbound $\mathrm{IgE}$ receptors may also be high. Accordingly, passive sensitization should in-crease both the contractile response and mediator rel-ease. We did observe such an effect in the present study. When isolated airways or lung mast cells were sensi-tized with atopic serum, we found that, consistently, both the contractile response to anti-IgE and the histamine release were increased (fig. 2a and table 1). The increa-sed responsiveness to anti-IgE in relation to passive sensitization of human peripheral airways was previously reported by RABE et al. [9]. Thus, anti-IgE mimicks more closely the specific antigen provided that peri- pheral bronchi are passively sensitized with atopic ser-um.

To directly demonstrate that the $\mathrm{IgE}$ concentration in atopic serum is responsible for the effect of either the specific antigen or anti-IgE, the effect of the atopic serum should be mimicked by IgE and a concentration-response relationship should be established. When isolated bronchi were sensitized with KHS supplemented with an IgE concentration similar to that of atopic serum (i.e. 1,000 $\left.\mathrm{IU} \cdot \mathrm{mL}^{-1}\right)$, contractile responses to anti-IgE were virtually indistinguishable from those obtained in tissues sensitized with serum (fig. 2a). A similar phenomenon was observed with histamine release (table 1). Moreover, when the $\operatorname{IgE}$ concentration used to sensitize isolated bronchi was altered, there was a concomitant alteration in the amplitude of the maximal contractile response to anti-IgE (fig. 2b). This relationship, that has been established in the present study by experimentally altering $\operatorname{IgE}$ concentration, supports the observation by RABE et al. [9] that the increase in the sensitivity of passively sensitized human airways to antigen depended on the level of specific $\operatorname{IgE}$ in the sensitized serum.

In conclusion, we found that the immediate hypersensitivity response in human airways and lung mast cells following sensitization with atopic serum was mimicked by sensitization with human monoclonal IgE in a concentration-dependent manner. The present study also indicates that anti-IgE mimicks more closely the specific antigen provided that peripheral bronchi are passively sensitized either with atopic serum or human monoclonal IgE. Further studies are required to determine the aetiology of the changes in the contractility of human airway smooth muscle induced by passive sensitization.

Acknowledgements: The authors are most grateful to the Service de Chirurgie Thoracique, Centre Hospitalier
Universitaire de Bordeaux for supplying the human tissue, and thank H. Crevel for technical assistance.

\section{References}

1. Burrows B, Martinez FD, Halonene M, Barbee RA, Cline MG. Association of asthma with serum IgE levels and skin test reactivity to allergens. N Engl J Med 1989; 320: 271-277.

2. Adams GK, Lichtenstein L. In vitro studies of antigeninduced bronchospasm: effect of histamine and SRS-A antagonist on responses of sensitized guinea-pig and human airways to antigen. J Immunol 1979; 122: 555562.

3. Undem BJ, Pickett WC, Lichtenstein LM, Adams GK III. The effect of indomethacin on immunologic release of histamine and sulfidopeptide leukotrienes from human bronchus and lung parenchyma. Am Rev Respir Dis 1987; 136: 1183-1187.

4. Black JL, Marthan R, Armour CL, Johnson PRA. Sensitization alters contractile responses and calcium influx in human airway smooth muscle. J Allergy Clin Immunol 1989; 84: 440-447.

5. Ellis JL, Hubbard WC, Neeker S, Undem BJ. Ragweed antigen $\mathrm{E}$ and anti-IgE in human central versus peripheral isolated bronchi. Am J Respir Crit Care Med 1994; 150: 717-723.

6. Marthan R, Crevel H, Guénard H, Savineau JP. Responsiveness to histamine in human sensitized airway smooth muscle. Respir Physiol 1992; 90: 239-250.

7. Villanove X, Marthan R, Tunon de Lara JM, et al. Sensitization decreases relaxation in human isolated airways. Am Rev Respir Dis 1993; 148: 107-112.

8. Ben-Jebria A, Marthan R, Rosseti M, Savineau JP. Effect of passive sensitization on the mechanical activity of human isolated bronchial smooth muscle induced by substance P, neurokinin A and VIP. Br J Pharmacol 1993; 109: 131-136.

9. Rabe KF, Morton B, Dent G, Colemean RA, Magnussen $\mathrm{H}$. Increased responsiveness to histamine, anti-IgE and allergen after passive sensitization of human airways in vitro. Eur Respir J 1993; 6: 481S (Abstract).

10. Mitchell RW, Rühlmann E, Magnussen H, Leff AR, Rabe KF. Passive sensitization of human bronchi augments smooth muscle shortening velocity and capacity. Am J Physiol (Lung Cell Mol Physiol 11) 1994; 267: L218-L222.

11. Mitchell RW, Kelly E, Leff AR. Effects of in vitro preconditioning on tracheal smooth muscle responsiveness. Am J Physiol (Lung Cell Mol Physiol 4) 1991; 260: L168-L173.

12. Holgate ST, Burns GB, Robinson C, Church MK. Anaphylactic- and calcium-dependent generation of prostaglan$\operatorname{din} \mathrm{D}_{2}\left(\mathrm{PGD}_{2}\right)$, thromboxane $\mathrm{B}_{2}$ and other cyclooxygenase products of arachidonic acid by dispersed human lung cells and relationship to histamine release. J Immunol 1984; 133: 2138-2144.

13. Okayama Y, Hunt TC, Kassel O, Ashman LK, Church MK. Assessment of the anti-c-kit monoclonal antibody YB5.B8 in affinity magnetic enrichment of human lung mast cells. J Immunol Methods 1994; 169: 153-161.

14. Andersson M, Nolte H, Olsson M, Skov PS, Pipkorn U. Measurement of histamine in nasal lavage fluid: comparison of a glass fiber-based fluorometric method with two radioimmunoassays. J Allergy Clin Immunol 1990; 86: $815-820$. 